\title{
ESOC 2018
}

$4^{\text {th }}$ European Stroke

Organisation Conference

16-18 May 2018/Gothenburg, Sweden

ESO - The Voice of Stroke in Europe

\section{CLINICAL CHARACTERISTICS OF ISCHEMIC STROKE IN PATIENTS TREATED PREVIOUSLY WITH DIRECT ORAL ANTICOAGULANTS}

Escribano Paredes, J.B1; De Felipe Mimbrera, $\mathrm{A}^{1}$;Nedkova Hristova, V11 Martínez Poles, J13 García Madrona, $\mathrm{S}^{1}$; Cruz Culebras ${ }^{1}, \mathrm{~A}$; Matute Lozano, $\mathrm{C}^{1}$; Vera Lechuga, $\mathrm{R}^{1}$; Masjuan Vallejo, J1.

${ }^{1}$ Hospital Universitario Ramón y Cajal. Madrid.

\section{INTRODUCTION}

Clinical guidelines recommend direct oral anticoagulants (DOACs) for secondary prevention of ischemic stroke (IS) in atrial fibrillation (AF). We present our clinical experience.

\section{METHODS}

Prospective registry (2010-2015) of patients with AF treated with DOACs in secondary prevention of IS. Demographic, clinical variables, IS recurrence and its management were analyzed.

\section{RESULTS}

${ }^{\star}$ Analysis of 425 patients with a meanfollow-up of $20 \pm 18,1$ months.

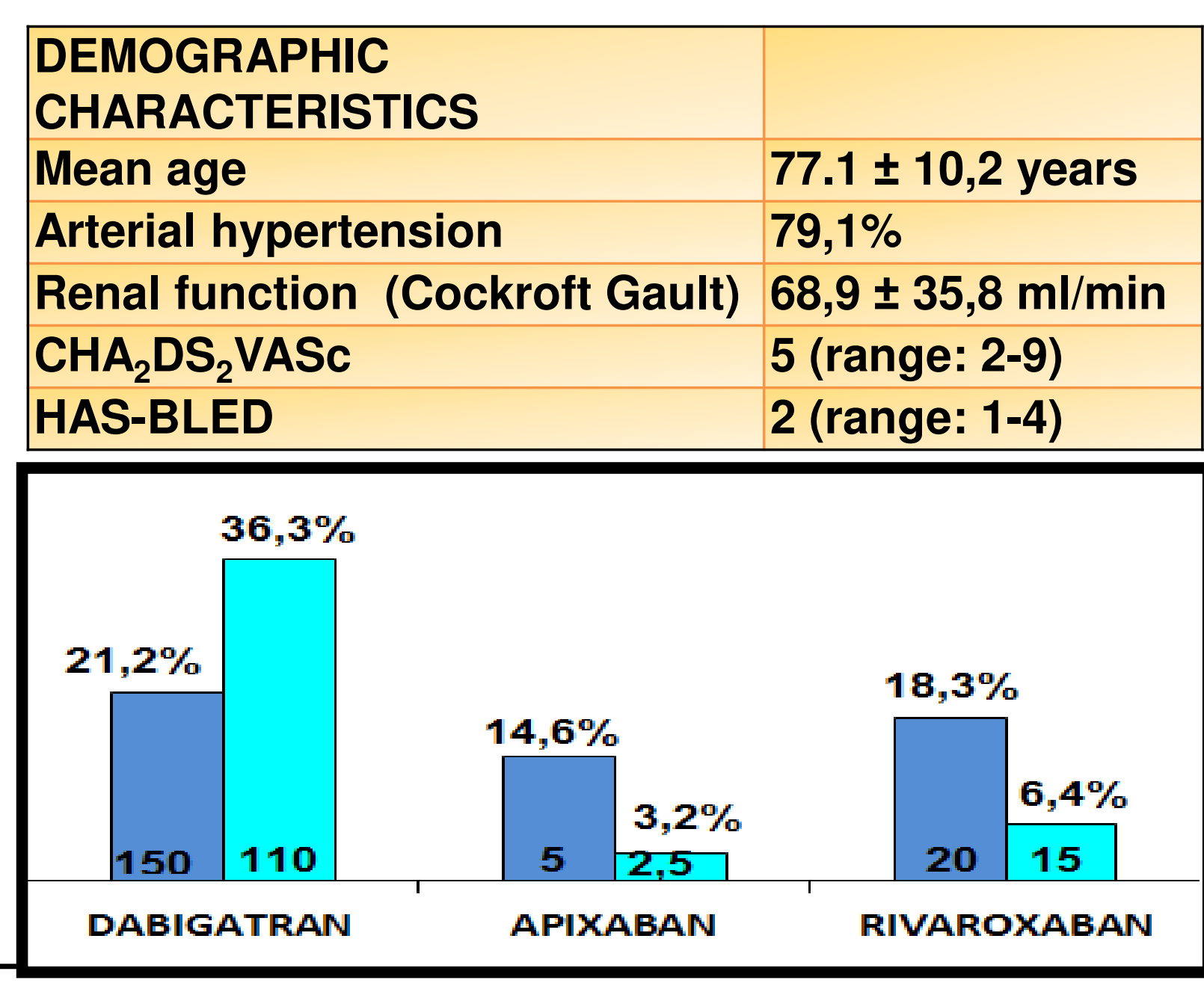

Monitoring loss: $40(9,41 \%)$.

․ Total deaths : $39(9,18 \%)$.

Anticoagulation-related deaths: $3(0,7 \%): 2$

hemorraghes and 1 isquemic stroke.

ISCHEMIC EVENTS

\begin{tabular}{|l|l|}
\hline & $\begin{array}{l}\text { Ischemic events } \\
\mathrm{N}=34(7,95 \%)\end{array}$ \\
\hline $\begin{array}{l}\text { Annual rate }=0,05 \\
\text { cases/person. year }\end{array}$ \\
\hline Mean age & 77,76 years \\
\hline Stroke deaths & $\begin{array}{l}1 \text { with Dabigatran } \\
110 \mathrm{mg}\end{array}$ \\
\hline Non-stroke deaths & 3 \\
\hline Time from treatment onset & $13,1 \pm 12,6$. \\
\hline $\begin{array}{l}\text { CHA }{ }_{2} \mathrm{DS} \text { VASc median } \\
\text { (range) }\end{array}$ & $6(2-8)$ \\
\hline HAS-BLED median (range) & $2(1-6)$ \\
\hline 3-month mRS & $2(0-6)$ \\
\hline
\end{tabular}

\begin{tabular}{|ll|}
\hline DABIGATRAN $150 \mathrm{mg}$ & $\mathbf{1 4 , 7 \%}(\mathrm{N}=5)$ \\
\hline DABIGATRAN $110 \mathrm{mg}$ & $\mathbf{5 0 \%}(\mathrm{N}=17)$ \\
\hline APIXABAN $5 \mathrm{mg}$ & $\mathbf{1 1 , 8 \% ( \mathrm { N } = 5 )}$ \\
\hline APIXABAN $2,5 \mathrm{mg}$ & $2,9 \%(\mathrm{~N}=1)$ \\
\hline RIVAROXABAN $20 \mathrm{mg}$ & $\mathbf{1 7 , 6 \% ( \mathrm { N } = 6 )}$ \\
\hline RIVAROXABAN $15 \mathrm{mg}$ & $2,9 \%(\mathrm{~N}=1)$ \\
\hline
\end{tabular}

\section{CONCLUSION}

In our experience with patients treated with DOACs in secondary IS prevention, incidence and clinical features of recurrent IS was similar to the pivotal trials. 